the thermal phenomena was very deficient. After describing his own observations made in the Pyrenees in July and August 1835, in the last section of his paper he extended his inquiries to the hot springs met with in other parts of Europe; and in particular, those of the baths of Mont d'Or and of Bourboule, in France ; of Baden-Baden, in Germany ; of Loèsche or Leuk, in the Vallais; of Pfeffers, in the canton of St. Gall, in Switzerland; and the baths of Nero, near Naples. Tables of observations were given with comparative columns derived from unpublished observations of Arago and Anglada.

\section{Geology of Scotland}

AcCording to the Edinburgh Philosophical Journal, at a meeting of the Wernerian Society held on April 16, 1836, "A notice was read on the dolomisation of the marble limestones, showing their magnesian character. The author also stated his views in regard to the geognostical relation of the Plutonian rocks of Skye, which he referred to the porphyry and trap formations. . . The blunders in observation, and the wholesale appropriation to himself of the geology of Scotland (in despite of all the published and un. published accounts of Scottish, English and German geologists) by Dr. MacCulloch, were noticed; and it was remarked by several members, that a better spirit was now generally abroad, and that few were disposed to follow in the path of the author of the Hebrides".

\section{Societies and Academies}

\section{PARIS}

Academy of Sciences, March 2 (C.R., 202, 705-784). The president announced the deaths of Charles Nicolle and Ivan Pavlov. ERnest Esclangon : The formulæ of Lorentz, and the principle of relativity. LUCIEN CUÉNOT : The coaptation of the anterior feet and of the head in Phasma. Edouard Chatton and Mlle. Srmone Brachon: The cinetome of Opalina ranarum, its genetic continuity and its importance with regard to the evolution of the ciliary apparatus. Jos. KAUCKY : The problem of iterations in a case of dependent probabilities. EDGar Batrcle : The problem of encounters. ALEXANDRE OsTrowskI : The conservation of the angles in the conformal transformation of a domain in the neighbourhood of a boundary point. Georges HartmanN : Certain properties of a Grassmanian. Charles Chartier and JEAN LABaT : The application of stereoscopic chronophotography to the kinematic study of gaseous outflow. Henr Lemonde: The interpretation of diffusion and viscosity curves in binary mixtures. Pierre VernotTe: The general laws of natural convection. Conditions for the appearance of the first regime. D. Milossavlisvirch: The use of the electronic tube as a detector utilising the curvature of the grid characteristic. Alexandre Dauvillier : A photomagnetron and its application to the measurement of twilight illuminations. P. CARRÉ : A practical rule leading to the interpretation of certain reactions of organic chemistry from the electronic point of view. L. NÉEL: The theory of volume anomalies of ferromagnetic substances. HENRI TRICHÉ : The spectrographic study of the modifications undergone by the surface of the light alloys. Application to duralumin. Constant Corin : The infra-red absorption spectra of the chlorine deriva- tives of methane. Jean Roulleau : The influence of temperature on the photo-electric effect of cuprous oxide-metal contact. The anomalies presented by the temperature coefficient of the photopotential are only apparent, and it is possible to define a temperature coefficient with constant contact resistance which depends only on the temperature and not on the cell studied. Maurice Curie : The theories of phosphorescence. The theory of Muto, based on the existence of a metastable state of the foreign atom, can be applied in the simplest cases, but other experimental facts have to be taken into account. RAYMOND LAUTté : The molecular volume of normal liquids. Albert Michel-LÉvy and Henri Muraour: The influence of the pressure of the surrounding gas on the luminosities accompanying the detonation of explosives. Increase of pressure of the surrounding gas considerably diminishes the intensity of the luminous phenomena, when lead hydrazoate is the explosive. Three photographs are reproduced illus. trating the effect of changing pressures. NÉDA MARINESCO : The law of blackening of photographic plates by ultra-sounds. The blackening by ultrasounds follows a law analogous with that of Hurter and Driffield. The results show that the photo. chemical action of light and that of ultra-sounds are identical. Marcel Godchot, Mlte. Germanne CAUQUIL and RAYMOND CALAS: The deuterhydrates of krypton and xenon. Forcrand showed that krypton and xenon can form hydrates with water containing approximately $6 \mathrm{H}_{2} \mathrm{O}$. The hydrates formed with heavy water are found to have the same composition. Paul Brasseur : The study of the anhydrous ferric phosphates with $\mathrm{X}$-rays. Four varieties of ferric metaphosphate give the same $\mathrm{X}$-ray diagram. Ferric pyrophosphate gave a different diagram, but no diagram characteristic of Millot's pyrophosphate could be obtained. Pierre SüE : The dehydration of some sodium niobates. EDOUARD RENCKER and MARC BASSIERE : The allotropic varieties of lead oxide. Lead oxide exists in two states ( $\alpha$ and $\beta$ ) characterised by their Debye and Sherrer diagrams. The thermal transformation of the $\alpha$-oxide into the $\beta$-oxide takes place suddenly at $530^{\circ} \mathrm{C}$. Morice LeTorT: A new polymer of acetaldehyde. The polymer recently described by Travers was noticed by the author in 1933, while preparing some highly purified acetaldehyde. Its properties agree with those given by Travers. One reaction in addition is given; the polymer reacts violently with fuming nitric acid and some nitrobenzene is produced. Martin Battegay and Pierre Boemler : The salts of $\alpha$ - and $\beta$-anthracenyl-diazonium. Pierre Comte : The lower Devonian of Léon (Spain). ROBERT LAFFITTE : The Jurassic and Berriasian in Aures (Algeria). ANdré Eichorn and Robert Franquet: Chromosome enumeration and the study of somatic mitosis in Asclepias cornuti. Serge TCHakhotiNe: The effects of localised irradiation of the nucleus of Infusoria by ultra-violet micropuncture. ERNDSI Kahane and Mlue. Jeanne Lévy: The diastatic hydrolysis of acetylcholine by serum.

\section{AMSTERDAM}

Royal Academy of Sciences (Proc., 39, No. 2, February 1936). F. K. TH. vaN Iterson : Cavitation and surface tension. Studies to determine the cause of the erosion by cavitation of the pumps used in draining the Zuider Zee. W. H. KeEsom and P. H. VAN LAER : Relaxation phenomena in the transition 
from the supraconductive to the non-supraconductive state. There is a relaxation time of $10-40$ sec. when the threshold curve is crossed by raising the tem. perature in the presence of a magnetic field. W. $H$. KEesom and $\mathrm{K}$. W. TACONIS : Crystal structure of solid oxygen. Confirmation of Vegard's results. J. G. VAN DER CORPUT: Distribution functions (5). E. CoHen and J. J. A. BLekkINGH, jun.: Influence of the degree of dispersion on physico-chemical constants (6). An effect of the degree of dispersion on the solubility of salicylic acid is observed. F. M. JAEGER and J. A. VAN DIJK: Complex salts of dipyridyl with bivalent and trivalent cobalt. A. A. NIJLAND : Mean light curves of long-period variables, 26.V18 =RZ Persei. This star has a complicated light curve with a main period of 354 days. P. H. vaN CitTERT: Some remarks on the resolving power of the microscope measured with Grayson's rulings. Influence of the kind of jllumination on the resolving power. L. HuLTHEN: The antiferromagnetic exchange problem at low temperatures. Calculation of the entropy and susceptibility. P. J. HARINGHUIZEN and D. A. WAS : Research on thin layers of tin and other metals (2). The corrosion of metals by technical insulating oils. Results for tin, lead and copper. W. Hurewicz: Contributions to the topology of deformations (4). Aspherical spaces. J. F. Koksma : Metrical considerations in the theory of diophantine approximations. J. BeINTEMA : Crystal structure of magnesium and nickel antimonate. The formulæ of both of these compounds is shown to be $\left\{\mathrm{M}\left(\mathrm{H}_{2} \mathrm{O}\right)_{6}\right\}$ $\left\{\mathrm{Sb}(\mathrm{OH})_{3}\right\}_{2}$. IDA LUYTEN : Vegetative cultivation of species of Hippeastrum (2). M. H. VAN RAalte : Influence of glucose on auxin production by the root tip of Vicia Faba. S. DE BoER and H. H. J. HoLTKAMP : Effect of medicines on auricular fibrillation (1). Experimental researches on the influence of hydroquinine, hydroquinidine, quinine and hydro. quinidine-free quinidine on auricular fibrillation of cats. B. VAN DER EYKEN: Denture and teeth development in the irisforelle (Salmo irideus) (3). Upper jaw. P. B. VAN WEEL : The periodicity in the metabolism of the recuperating pancreas of the white mouse. Flisabeth A. RIETMEYER and F. J. NiEuwenhuyzen : The action of guanidine derivatives on motility. C. D. VerriJP and E. F. Drion : Frequency distribution of growth in homogeneous material (1). Experiments on Kalanchö̈ verticillata considered in relation to statistical theories of Pearson, Kapteyn and others.

\section{CRACOW}

Polish Academy of Science and Letters, February 5. W. SterPINSKI : A universal function of two real variables. S. RUZIEwICZ : Remark on universal functions of two real variables. L. JANsons: The Zeeman effect of the forbidden lines of the helium spectrum. T. Banachiewicz : A new minor planet. This planet was discovered on plates taken at Cracow by $\mathbf{K}$. Stein on January 24,1936 , and the position is given. It is possible that this planet may prove identical with the planet $1936 A B$. K. DzimwonskI, T. MAJewrcz and L. SchImmer : New studies on the bisubstituted derivatives of naphthalic acid. B. HRYNIEWIECKI and MLle. W. KuRTz: The distribution of the siliceous cones in the cells of the Cyperaces and their correlations. J. MотYKA : A monograph of the genus Usnea. H. SzarskI : Contribution to the study of the physiology of the worms included in the genus Chatogaster. J. ZACWILICHOWSKI : Researches on the innervation of the sensorial organs in the wings of Aphrophora alni. J. TUR: A double neoplastic embryo. P. StonImskr: The figured elements of the blood of Amphiuma means.

\section{Geneva}

Society of Physics and Natural History, February 6 . E. Guyenot, E. Held and A. Moszkowska : (1) Habituation to prehypophysal hormones. (2) The production of anti-hormones in the serum of habituated animals. Female guinea pigs, after prolonged treatment with prehypophysal extracts, become refractory to the action of these hormones. Experiments prove that this is the result of the production of anti-bodies, present in the serum and capable of conferring a passive immunity on fresh animals. A. JAYET : Some new observations on the Magdalenian of Veyrier sous Salève (Hte. Savoie). A. Perier : 'Various anatomical types of the tubercle of Carabelli W. H. Schopfer and A. Jung: Researches on the measurement of vitamin $B_{1}$ activity with the aid of a micro-organism (Phycomyces). A certain number of substances, known for their content of vitamin $B_{1}$, are examined simultaneously with the test animal (rat) and plant (Phycomyces). The results are partially satisfactory. If, in a concentrated extract, the vitamin $B_{1}$ is the only effective factor, the plant test is susceptible of practical applications, at any rate in certain cases.

February 20. A. Lendner : Hereditary 'alcoholism' in the bean (Phaseolus vulgaris). CH. BaEHNI: A new genus of the family of the Icacinaceæ, Neoloretia. B. Susz and E. Perrotret : The Raman spectrum of isoeugenol and of the safrol series.

\section{Moscow}

Academy of Sciences (C.R., 4, No. 4-5; 1935). L. V. KaNTOROVITCH : Some particular methods of prolongation of Hilbert space. A. TrchoNov: Mathe. matical theory of the thermo-electric couple. V. Fabrikant, F. Butajeva and J. Cirg: Influence of pressure on the discharge radiation in mercury vapour. A. V. Solovjev : (1) Effect of the water vapour pressure on the rate of the interaction between iodine and metals (iron and copper). (2) Interaction between aluminium and iodine in an air atmosphere of varying humidity. A. PoLEssitskiJ : Solubility and activity of the halogenates of some bivalent metals. (1) Solubility and activity of $\mathrm{Ba}\left(\mathrm{IO}_{3}\right)_{2}$ in water and in solutions of electrolytes. (2) Solubility and activity of $\mathrm{Pb}\left(\mathrm{IO}_{3}\right)_{2}$ in water and in solutions of electrolytes. K. S. TopciJev : Cases of mobility of the nitro-group. A. VEDENEJEVA, S. Grumgrzimajlo and A. Volkov: Microscopic determination of the refractive indexes of resinous substances of highly refractive minerals. Z. KaTzNELSON: Sources of development of the lateroventral part of the trunk muscles and the caudal muscles in Amphibia. The muscles develop from the mesenchyme. A. J. Charite: Flavins and metabolism. (1) Flavins and amylolysis. (2) Flavins and proteolysis. S. I. KRAJEvoJ and R. A. RAsSULY : Frequency of translocations in different sections of the chromosome in Pisum. A. F. BuchinskiJ : Inheritance of duration of vegetative period in tobacco. V.I. KRokos: Stratigraphy of the quaternary deposits of the south-western portion of the ice lobe in the Don River basin. 


\section{ROME}

Royal National Academy of the Lincei (Atti, 22, 1-91 ; 1935). G. A. Crocco : Safety of gliders on encountering an ascending gust. P. Alorsi : Some flint-stones of anagenite-verrucano from Monte Pisano. L. Toscano: Permutable operators with the power of a special linear operator (2). L. Ermolate : Surface couples with corresponding asymptotes and having a pair of common conjugate straight lines at homologous points. A. ToNoLo: Integration of the differential system of Dirac. R. WorNarosk $\ddot{Y}$ : Kinematies of a solid body in Euclidean space of $n$ dimensions. N. Spampinato : Extension to the bicomplex field of two theorems of Levi-Civita and of Severi, through the holomorphous functions of two complex variables (1). G. Scorza DragonI : Some theorems relative to a problem of limits through a differential equation of the second order. G. Mattioli : Internal forces in turbulent media and general equations of turbulence. D. GRAFri : Effect of variation of mass on a planetary orbit. N. W. Akrmoff : The paradox of Dubuat. C. M. MaLdura : Chemical researches on the Orbetello lagoon with regard to the biology (1). A. SpIRITo : Influence of continuous electric current on meristems of roots. G. SchreIBER : Atypical regeneration of the limbs of Proteus anguineus, Laur. M. Romano and G. SCHREIBER : Changes of the eye of Anurans during normal and accelerated metamorphosis. V. FAMIANI : Anti-neuritic vitamin $\left(B_{1}\right)$ content of germinating grain, and of some varieties of Italian grain. T. DE Sancis Monaldi : Experimental human malarial infection from sporozoites.

\section{VIENNA}

Academy of Sciences, February 20. RICHard SchumanN : Report on further investigations of latitude variations. OTTO DISCHENDORFER and August Verdino: Condensation of benzoin and thymol (1). Preparation of 2-benzoyl thymol and determination of the constitution of desyl thymol. Josef A. Priebsch : Study of the secondary radiation of cosmic rays at $2,300 \mathrm{~m}$. by counters. The number of coincidences recorded at high altitude by three counters arranged in a triangle below a sheet of scattering material varies more with barometric pressure, temperature, and time of day than either the total or the vertical radiation. EuIse HoFmanN : A silicicated palm in the Tertiary at Retz (Austria). ERNST MELAN : Theory of statically indeterminate systems made of ideally plastic material. GerHARD HEINRICH : Theoretical and experimental study of the water-jet suction pump. R. JAGITSCH : Reactions in the solid state. E. HAYEK : Crystallisation and dehydration of copper hydroxide. ODOMAR GUGEnBERgER: (1) The Trias at Eberstein (Carinthia). Ninety further species have been distinguished in the fauna of the Cardita-bearing stratum at Eberstein. Of these, fifty-nine have previously been found in the related Launsdorf deposits, while of the remainder nine are entirely new. (2) Unknown species in the sub-Lias (Buckland zone) of the province of Palermo.

February 27. KarI GIRKMANN : Yielding of tie rods under local loads. F. WESSELy, K. SchönOL and W. IsEMANN : The bitter principle of Columbo wood. HERBERT ScHOBER : Study of the spectra of the inert gases by means of a short wave generator.

\section{Forthcoming Events}

Chemical Society, April 16-17.-Anniversary Meeting to be held at Bristol.

April 16, at 4.45.-Presidential Address. Dr. N. V. Sidgwick.

April 17, at 11.30.--Prof. T. S. Moore: Hatzsch Memorial Lecture.

Geographical Association, April 17-20.-Spring Con. ference to be held in the University of Sheffield.

British Psychological Society, April 17-20.-Extra. ordinary General Meeting to be held in Leeds.

\section{Official Publications Received}

\section{Great Britain and Ireland}

Falmouth Observatory. Report of the Observatory Committee to the Royal Cornwail Polytcchnic Society and the Falmouth Toun Council. By H. Dent Gardner; with Meteorological Notes and Tables for the Year 1935, also Additional Meteorological Tables for the Lustrum 1931-1935, with Mean Values for 65 Years (1871-1935), by W. Tregoning Hooper. Pp. 17. (Falmouth : Falmouth Ohservatory.) [193 The Board of Greenkeeping Research. Report for 1935 . Pp. 54 . (Bingley : St. Ives Research Station.) (N.S.), No. 31: The Preparation of Alginic Acid and its Constitution. By Vincent C. Barry and Dr. Thomas Dillon. Pp. 285-287. 6d. Vol. 21 (N.S.), No. 32: Derivatives of Alginic Acid, Part 1: The Acetyla. tion of Alginic Acid, By Vincent $\mathrm{C}$. Barry, Dr. Thomas Dilion and Pádraic O’Muineacháin. Pp. 289-296. 6d." (Dublin : Hodges, Figgis and Co. ; London: Williams and Norgate, Ittd.)

\section{Other Countries}

Indian Forest Records. New Series, Vol. 1, No. 11: New Indian Curculionidae (Col.). By Sir Guy A. K. Marshall. Pp. 205-232.

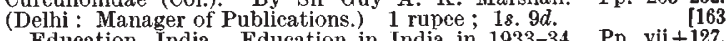
Education, India. Education in India in 1933-34. Pp. vil +127 . Delhi : Manager of Publications.) 2.2 rupees; 48. Ministry of Finance, Egypt : Survey of Egypt : Geological Survey. Leaves of Dicotyledons from the Nubian Sandstone of Egypt. By Prof. A. C. Seward. Pp. iii $+23+3$ plates. (Cairo: Government
[233 Kungl. Svenska Vetenskapsakademiens Handlingar. Serien 3, Band 15, No. 3: Additional Cretaceous Plants from Western Greenland. By A. C. Seward and Verona Conway. Pp. $41+6$ plates. (Stockholm: Almquist and Wiksells Boktryckeri A.-B.) [233 Report of the Aeronautical Research Institute, Tôkyô Imperial University. No. 133 : Experimentelle Untersuchungen über AugenBlendung. Von Yenziro Awadi. Pp. 60, 55 sen. No. 134: On the Directional Properties of Airscrew Sound. By Juichi Obata, Yahel Yosida and Umezirô Yosida. Pp. 61-79. 35 sen. (Tokyo: Kogyo
Tosho Kabushiki Kaisha.)

Indian Forest Records, New Series. Vol. 1, No. 2 : Experiments on the Air Seasoning of Softwood Railway Sleepers. By Dr. S. N. Kapur, assisted by Azizul Rehman. Pp. iv $+43-75+2$ plates. (Delhi : Mansger of Publications.) 1.4 rupees; $2 s$.

Smithsonian Institution: 'United States National Museum. Contributions from the United States National Herbarium, Vol. 26, Part 8: New Species of Pilea from the Andes. By Ellsworth P. Killip. Pp. viii + 367-394. (Washington, D.C.: Government Printing Office.) 10 cents.

Smithsonian Miscellaneous Collections. Vol. 95, No. 1 : Observing the Sun at 19,300 feet Altitude, Mount Aunconquilcha, Chile. By C. P. Butler. (Publications 3379.) Pp. ii +4. Vol. 94, No. 17: Growth of a Green Alga in Isolated Wave-Length Regions. By Florence $\mathbf{E}$. Meier. (Publication 3377.) Pp. ii +12+1 plate. (Washington, D.C.: Smithsonian Institution.)

U.S. Department of Agriculture. Technical Bulletin No. 486 : Cotton Bollweevil Survival and Emergence in Hibernation Cages in Louisiana. By R. C. Gaines. Pp. 28 . 5 cents. Technical Bulletin No. 499 : The Cannibalistic Habits of the Corn Ear Worm. By George W. Barber Pp. 19. 5 cents. Technical Bulletin No. 502: The Chemical and Physical Properties of Dry-Land Soils and of their Colloids. By Irvin C. Brown and Horace G. Byers. Pp. 56. 10 cents. (Washingtos D.C. : Government Printing Office.)

U.S. Grovernment Printing Onfee.) . Office of Education. Bulletin 1935. No. 2: Statistics of Private Elementary and Secondary Schooks 1932-33. (Being Chapter 6 of the Biennial Survey of Education in the United States, 1932-34.) Pp. 71. (Washington, D.C.: Government Printing Office.) 10 cents.

\section{Catalogues}

The Wild-Barfield Heat-Treatment Journal. Vol. 1, No. 8, March. Pp. 97-110+iv. (London: Wild-Barfield Electric Furnaces, Ltd.) Radiography and Clinical Photography. Vol. 1, No. 1. Pp. \&

London : Kodak, Itd.) and other Laboratories. Pp. 58. (Wallsend-on-Tyne: The Thermal Syndicate, Ltd.)

A Complete List of Chapman and Hall's Scientific and Technical Books. Pp. 158 + xxxviii. (London: Chapman and Hall, Itd.) 